\title{
Diverse human families and pet friendly work environments: Pawternity of dogs
}

By:

Maria Alejandra Gonzalez-Perez, Universidad EAFIT, Colombia Andri Georgiadou, Cyprus University of Technology, Cyprus

\section{Abstract:}

- Purpose:

This paper of exploratory nature aims to provide an account of the reviewed literature and presenting some empirical cases to come to conceptualize dogs as social actors with different legitimate roles in the working, social, private, economic and family life of human beings.

- Design/methodology/approach:

This paper is the product of a research inspired by the great interest of the authors on rising awareness of the importance of dogs in human working lives. For this, a purposive literature review took place; we consulted scientific studies databases, and also gathered information from market research agencies, and other general media resources. To have a more comprehensive view, and to responding to a specific question on dogs at the workplace, a selection of cases are used to illustrate. For the case studies, secondary data research was used, and individual, structured interviews were conducted and analyzed.

- Findings

This paper reviews the relationship between humans and people. It identifies attitudes and perception towards animals, highlighting the evolution of the intimate bond and the deep relationship between dogs and humans. It describes some cases of dogs as working beings at the service of human functions, and describes dimensions of the pet care markets. Finally, it presents some cases of pet-friendly work environments.

- Originality/value

The novel contribution of this paper is putting dogs in the management of diversity academic literature. In this study, we find that the role, meaning and purpose of dogs in people's lives (and in many cases in organizations) is being underestimated. Including and making visible the presence of dogs in the personal, work and wellbeing of people represents challenges to be addressed by managers. Additionally, it represents challenges to think about and investigate the welfare of dogs that interact with human beings in productive environments.

\section{Keywords:}

Pet-friendly work environment; diverse families; dogs at work; human-animal relationships; Pawternity 


\section{Human-animal relationships}

Changes in lifestyles and evolutionary patterns have made pets more and more an integral part of many people's lives. The relationship between human and animals has many dimensions. The first dimension that emerged already from prehistory is related to the use and exploitation of animals to fulfill basic human needs such as food and protection (Urichuk \& Anderson, 2003).

Another dimension of this relationship extends beyond the needs of human survival and is related to its well-being. The human-animal bond has been scientifically explored and proves to provide significant physical, psychological and physiological benefits to human well-being (Jackson, 2012).

An important dimension, finally, of the relationship between humans and animals is related to the latter's involvement in activities for educational purposes. This includes them being studied in the context of lessons so for children to get familiarized with living organisms, participate in action research and experiments, as well as in various educational programs aiming at raising awareness and cultivating respect and responsible behavior towards other animals specifically, and as a consequence to nature in general (Cunningham, 1995).

The relationship with other animals begins from the childhood of individuals. This connection of children and animals is indisputable. Animals are, of course, part of the child's micro-world, and in the United States around $70 \%$ of households a pet (APPA, 2018). But even when there is no pet in the families, children are surrounded by animals from a very young age. They have puppies, kittens, giraffes, monkeys and teddy bears in their clothes, in their games, on the walls of the schools. They come in contact with animal characters through cartoons, stories in books, movies and videos, through computer games and the internet while gaining experiential experiences by visiting zoos and farms (Walsh, 2009).

For children, the existence of a pet in their life is very important. A research study indicated that, children aged between 7 and 10 when asked to make a list of the ten most important persons in their lives, they included two pets on the list (Foer, 2006). In a similar survey, a question about to whom the children would go to if they felt sad, angry, happy or wanted to share a secret, almost half $(42 \%)$ of children aged 5 years old responded to their pet (Foer, 2006).

Further research has dealt with the contribution of animals to the smooth cognitive and behavioral development of children. The results of these studies have shown that the presence of animals in the life of children, whether real or imaginary and symbolic, contributes to their positive psychosocial development. Children who have an animal at home or have a daily interaction with animals exhibit greater selfesteem, cognitive and emotional development, social interaction and empathy (Poresky, 1990; Triebenbacher, 1998). Finally, the interaction of children with animals can work educationally and instructively by helping them coping with serious issues of childhood such as separation from beloved persons, death and autonomy (Walsh, 2009). 


\section{People's attitudes towards and perceptions of animals}

The increasing number of companion animals is a response to demographic and sociological changes: growing number of urban and aging population, with smaller and more fragmented families than in the past century (Hall, Bristol, Fuller \& Mills, 2017).

The knowledge that people have about animals influences their behavior towards and beliefs about them, so building positive attitudes towards animals is one of the main goals of environmental education. Researchers suggest that attitudes are related to awareness but an even greater correlation is observed between attitudes and behaviors; changing knowledge and understanding of animals can affect animal perceptions (Batt, 2009). In light of this, the environmental education includes information to enhance environmental knowledge but also other factors so as to achieve the manifestation of (environmental) attitudes and behavior (Thompson, 2009).

Some researchers believe that environmental knowledge is the precursor to the formation of attitudes towards the environment and therefore to animals. However, the relationship between attitudes and knowledge is more complex than it seems. In his research, Cohen (1973) showed that a group of students with more environmental knowledge had different attitudes than a group of pupils with less environmental knowledge. In a survey conducted by Hsu and Roth (1996) in Taiwan, the relationship between environmental attitudes and behaviors has been investigated and a positive correlation between environmental knowledge and behavior was found.

There are various factors affecting the attitudes towards animals. Firstly, people's attitudes towards animals vary according to the species of animals. Bjerke and Østdahl (2004) found that humans are more positively related to the smallest animals, such as small birds, squirrels, dogs etc., and dislike invertebrates, bats, rats and mice. In contrast to the above finding, Kellert (1997) found in his research that adults have a more positive attitude towards in large animals, especially those with high intelligence and social connectivity.

Secondly, differences in people's attitudes also exist between men and women. Women appear to have a greater humanitarian and empathetic disposition than men. In a survey conducted in 15 countries and assessing people's attitudes towards the use of animals in biomedical research, women were significantly more opposed than men in the use of animals in experiments (Pifer, et al., 1994). On the other hand, men seem to have more positive attitudes towards species that are not particularly popular, such as wild animals and exotic birds, while women have more positive attitudes towards more popular species such as pets (Bjerke \& Østdahl, 2004) (Lindemann- Matthies, 2005).

Finally, culture seems to be influencing significantly the attitude towards. To investigate this further, Kellert (1993) undertook a series of intercultural research. In a survey he conducted in Japan he found that compared to the American population, the Japanese population has more sovereign attitude towards nature and wildlife. That is, the Japanese often try to manipulate and control nature. There was also a 
lack of interest in wildlife and ecological processes, and limited support for wildlife protection. Unlike the Japanese, the Germans was proved to have more developed moral and ecological attitudes and greater willingness to subordinate their needs to preserve nature and wildlife.

\section{Human-dogs relationships}

The global dog population is estimated to be 900 million (World Atlas, 2018). In the United States, there are nearly 80 million dogs (Serpell, 2017; Statista, 2018). In the United Kingdom there 65 million of companion animals (Hall, Bristol, Fuller \& Mills, 2017).

Dogs play different roles as family members, and valued assistants. Nonetheless, only a very small percentage work or hunt (Lord, Schneider \& Coppinger, 2017). In fact, "the domestic dog has become something of a scientific celebrity in recent year" (Serpell, 2017, p. 2).

The canidae is a group of terrestrial mammal carnivores divided into 36 species including the domestic dog (canis familiaris), foxes, coyotes and other canids (some already extinct) (Clutton-Brock, Corbet \& Hills, 1976). Canids communicate with each other through facial expressions, body postures, body movements and in some cases sounds. Since before Charles Darwin there have been discussions and studies to determine the ancestry of domestic dogs, since they have been considered as descendants of wolves (canis lupus)or golden jackals (golden aureus) or other extinct species. However, Darwin (1868) considered that perhaps this could not be determined with certainty.

Those who have found evidence that domestic dogs are descendants of wolves, consider that dogs have inherited from the wolf essential biological characteristics including social behavior in herds, which has coincidences with human families among which are territoriality, cooperation to go hunting, respect for leaders (alpha), emotional connections and greetings after separating.

Dogs and humans have lived together for thousands of years. Nicky Charles, director of the Center for Women and Gender Studies at the University of Warwick in England, has been investigating the link between humans and non-human animals, and in an article from the year 2016, which reports the results of a study with empirical data, she argues the emergence of post-human families, or families more than human. This sociological investigation explains how power relations between humans and dogs are unequal, and therefore dogs (and other companion animals) incorporated into families are dependent (Charles, 2016). For this reason, we are responsible for their well-being (as if they were infant children).

My dog is my home

"My Dog is My Home" is a project in Los Angeles, United States, dedicated to sharing the testimonies of the bonds of care, empathy, reciprocity and love between homeless or street people and their fellow dogs (My Dog is My Home, 2018). Researchers Kathryn Gillespie and Victoria Lawson (2017) studied the politicization 
of species relations, structural violence and poverty, which reproduce concepts based on the material conditions of property, home and family, thus achieving human lives and animals in street situations are perceived as disposable.

\section{The deep bond}

In spite of not having a consanguineous link, for many people the planning of the arrival, the care, the upbringing, the possession, the education and the coexistence with a dog or another animal of company is an exercise of maternity / paternity. The humanization of pets has been evolving giving them roles of companionship, therapy, friendship, and treating them as children.

Since the 1950s, John Bowlby (1958) defined attachment as an organizational construct that develops the emotional bond between human babies and their caregivers. According to Bowlby (1958), the function of attachment in the first years of life is to get protection and care from another person, and this is done by seeking to adapt the behaviors of the caregiver (usually the mother). More recent studies (Beetz, Uvnäs-Moberg, Julius, \& Kotrschal, 2012) have found that attachment styles are a combination of genetic factors and social experiences.

The ability of dogs to develop attachment to humans is one of the most recognizable consequences of their domestication, and the way they develop affection is analogous to the attachment between human babies and their mothers (Topál, Miklósi, Csányi \& Doka, 1998). A study published by Kovács and colleagues (2018) found that the (mutual) attachment of dogs and their owners is associated with polymorphisms of the oxytocin receptor gene (OXTR) in both parts (thus dogs are obviously not genetically related to their caregivers), but also influenced by the personality of the dog owner and the attachment style.

In a study led by the team of Samantha Deffler (2016), it was demonstrated how in the human memory the dogs of the home are cataloged as family members. There are few lapsus linguae where one of the members of the family is called by the name of the dog. According to the study by Deffler and her colleagues (2016), these errors in calling or referring someone by name do not occur because we confuse the species or the gender of friends or relatives, but it has to do with the way in which the brain Classify the information. According to this research, these lapsus linguae happen with dogs, but not necessarily other pets. One of the reasons is that people communicate verbally more with dogs than with other types of pets. However, the research indicated that perhaps the substitution of the name of a human member of the family for the name of the dog occurs because the brain does not classify the family names between humans and animals.

In an attempt to tackle mental disorders and promote mental health and well-being, specialists highly recommend physical activity as an essential part of their patients' therapeutic plan (Morgan \& Goldston, 2013). To complement this, an auxiliary "animal assisted therapy", "pet therapy" or simply a form of treatment with animals is gaining ground recently. Dogs, cats, horses or even farm animals have been proved to be very effective therapeutic agents. Animal therapy has been effective in treating people of different ages with special medical needs or mental conditions such as attention and social behavior, mood disorders, anxiety, fear, and cardiovascular 
diseases (Fine, 2010). The benefits of this contact are found to be physical, mental and social (Kovács, et al., 2004). Specifically, the therapeutic contact with animals seems to reduce levels of fear, sadness and psychological discomfort and promote psychological well-being (Klontz, et al., 2007). It also improves self-esteem and helps dealing with various stressful situations (Berget, et al., 2008; Pedersen, et al., 2012); it can help reduce the somatization of psychological problems (Schenk, et al., 2009), reduce depressive symptoms (Nepps, et al., 2011) and anxiety (Hoffmann, et al., 2009; Lang, et al., 2010), whereas it minimizes the emergence of violent episodes for patients with severe chronic psychiatric disorders (Nurenberg, et al., 2011).

Human contact with animals and the bond developed between them had been occurring since human beings began to domesticate the latter and transform them into domestic animals in order to benefit from them in hunting and carrying burdens (Urichuk \& Anderson, 2003). There have been several archaeological findings that testify the contact and the relationship that existed between human and animals, such as fossil representations and references within archaeological texts (Fradelos, 2014). Reports indicate that ancient Greeks used the horses as an auxiliary means for the treatment of war wounded soldiers (Riede, 1987), justifying the peculiarity and timelessness of this bond (Fine, 2010).

Although the first written reports on the engagement of animals into a therapeutic approach can be traced back to 1792 (Trivedi \& Perl, 1995), the systematic treatment of animals as therapeutic agents has only begun in the $19^{\text {th }}$ century. As Nightingale (1992) points out, a small pet is often a great companion for the patients, especially for the chronic ones. A bird in a cage is sometimes the only real pleasure for those staying in a nursing home for years.

Since 1960, pet animals have been incorporated into the curative environment by Boris M. Levinson; a child psychotherapist and author of Pet-Oriented Child Psychotherapy (Levinson, 1969). In this book he describes the procedures and benefits of sessions he had with children in which his dog was present as well. He emphasizes the various beneficial effects and encourages further research on this issue, thus opening a new potential avenue for psychotherapy.

\section{The public life of pets}

Parks and many public spaces are places where the interactions between dogs and humans are increasingly frequent ${ }^{1}$. For Simon Carter (2016), a professor of urban planning at the University of Melbourne in Australia, park planning is based on anthropocentric values, parks being spaces primarily designed to meet community priorities, and although dogs are an important interest group of park users. the urban parks, the design of parks in the cities still exclude them in the planning.

Around the world, shopping centers, restaurants, hotels, schools, universities, airlines and other public establishments have been adapting to allow and regulate

\footnotetext{
${ }^{1}$ Interestingly enough, as we were preparing this chapter, Limassol's (Cyprus) municipality has banned dogs from one of the biggest parks in Limassol; a decision that has been strongly criticized by animal lovers around the country (https://cyprus-mail.com/2018/08/29/limassol-municipality-says-dogban-due-to-law-breaking-owners/)
} 
the presence of dogs and other pets within the facilities. Even, several companies, as it is going to be described further in this chapter, have established codes of conduct and have declared themselves "pet friendly" allowing their employees to go to work in the company of their pets. In some countries, including Colombia, dogs and any other pets whose size is below $60 \mathrm{~cm}$ are eligible to use public transportation.

\section{Working dogs}

Working dogs are now used as reliable assistants in challenging occupations, such as the Police for the detection of illegal substances and explosives or the detection of missing persons, the Fire Brigade as rescue dogs, or even the Red Cross, where they tirelessly climb the frozen mountain peaks in search of lost hikers and skiers (Sloane, 1955). And the list does not end here. In the dawn of history, people used dogs to assist them in their military activities, whereas nowadays dogs are also used as service dogs; assistance dogs; security dogs; shepherds; breeders and disease biosensors. In the latter case, these are dogs that have been trained in recent years so as to use their extremely sensitive sense of smell to detect pathogens and diseases (Angle, Waggoner, Ferrando, Haney, \& Passler, 2016).

\section{Police dogs}

Out of various types of biological organisms that are used as volatile compound detectors the most known and widely used are canines (Leitch, Anderson, Kirkbride, \& Lennard, 2013). Literature indicates that there are more than 30 different sets of detection tasks that trained dogs can perform making them ideal police candidates (Lorenzo, et al., 2003). The duties of police dogs all over the world include mainly explosives and narcotics detection, as well as patrolling.

Specifically, explosive detection dogs help the police forces to detect explosive devices and to thorough search buildings, vehicles and spaces. Their excellent smell leads to a more effective detection of explosives and exploration of spaces, which takes place either preventively or upon receipt of relevant information about the existence of certain substances. These dogs perform a plethora of precautionary investigations daily, in addition to the response to threatening phone calls. When the dog detects the exact location of the explosives, they are trained to sit and remain silent in that position while maintaining a passive stance (Furton \& Myers, 2001). Furthermore, drugs detection dogs assist police officers in examining individuals, vehicles and premises. Their effective smell identifies well-hidden drugs, which are difficult or often impossible to locate with human senses. If there are drugs, even carefully hidden, at high points or buried or mixed in liquids with various other misleading smells, the dog will detect them. When locating them, the dogs are trained to actively respond by carving and barking.

Finally, patrol dogs support policing on a multifaceted basis. They are used in places where there is intense criminality, but at the same time in places with dense flow of people. They are one of the best crime deterrents used by the police worldwide with massive positive results. By all means, they do not substitute for other policing methods, but they modernize, complement and reinforce the effectiveness of policing based on psychological influence and real-time circumstances of action. The patrol 
dog is an effective preventive and deterrent tool to help curb violence of any origin and form. They have advanced sociability and will execute actions only on command, which, of course, will be given solely by their companion and merely to prevent criminal felony acts.

The breeds that have been used so far as a pool for police dogs candidates, are German shepherds, Golden retrievers or Labradors and Malinois (Belgian shepherds) due to their abundance in the domestic and European markets. They are three easily trained breeds and are very social, disciplined and receptive dogs, offering their services in the detection of drugs or explosives and the strengthening of pedestrian patrols. Nowadays, the dog's selection process has changed and a dog's fit in the police force is not decided on the grounds of its breed. In contrary, each dog's characteristics, abilities and skills are evaluated individually. Following the evaluation, they are been trained on the field that had best performed in, regardless of their breed.

\section{Service dogs}

On the one hand, treatment dogs are trained to be able to accompany their owners to access buildings (including restaurants, libraries, supermarkets, and churches), transport systems, and other public spaces and services.

On the other hand, assistance dogs are domestic dogs, specially trained to help people with diabetes or mobility problems in order to improve their quality of life. Assistance dogs can learn to perform various tasks, such as leading people with partial or total blindness or deafness, pulling wheelchairs and alerting in case of hypoglycemia crisis.

In theory, all breeds can be used as service dogs and therefore as diabetic alert dogs. However, short-breasted breeds are not indicated for becoming ones, because a shorter nose means that the odor entering the nasal cavity is processed by less tissue. This makes them lagging behind the longer-breed races. In light of this, the required characteristics of the dogs and by extension their breed, depends on the specific type of service they will be performing.

For example, Golden Retrievers and German Shepherd are common choices for blind people due to their helpful characteristic; their temperament, flexibility, size, intelligence and availability.

Guide dogs must be hard working, and large enough to be able to guide people. At the same time, they should be tied up with a small leash to make it easier and more comfortable for people to move to public transport, and for the dogs to fit under the tables of the restaurants. Labrador Retrievers make excellent guide dogs, because they are very intelligent, quick learners and extremely loyal.

Service dogs have special functions in addition to those described. Mader, Hart and Bergin (1989) found that the service dogs that accompany people in wheelchairs are also very useful to overcome social isolation. Through observations, it was determined that when adults and children in wheelchairs have a service dog, these 
people receive greater social acknowledgments than when they do not have a dog with them.

There are different studies (Hoffmann et al, 2009; Lang et al, 2010) that document assisted therapies with different animals to improve mental health and reduce the anxiety of some patients. Those studies determined that the presence of dogs produces significant psychotherapeutic benefits, especially in the reduction of anxiety, and in increasing the motivation of therapists and patients.

\section{Disease biosensors}

Williams and Pembroke (1989) described the story of a woman who realized that something bad was happening when her dog suddenly began to look overly interested in a mole on her leg. When she started looking for what was happening, she discovered she was suffering from skin cancer. This may have been the first story that was published and linked the dog with the detection of cancer, but it was not the last one. It was even a source of inspiration for an orthopedic surgeon, Dr. John Church, who wanted to find out exactly how these brilliant animals manage to sniff out cell carcinomas (Church \& Williams, 2001).

The enormous interest in the subject led researchers to establish the Cancer and Bio Detection Dogs in 2008 (Medical Detection Dogs, 2018); a research center were dogs are trained to sniff out instant fluctuations in an individual's personal odor triggered by their disease and alert them to an approaching medical event. Within just the first ten years of operation of the Center, another 16 cases of early cancer detection have come to light. As Dr Claire Guest, Co-Founder, CEO and Director of Operations claims, the research team has been aiming to prove scientifically that people's best friend can indeed be trained to detect cancer, and possibly other diseases.

\section{Livestock guardians and herding dogs}

Livestock guarding dogs are estimated to be the most populous working dog in the world (Lord, Schneider, \& Coppinger, 2017). These dogs are prevalent and adjunct to pastoral cultures and communities. Lord et al (2017) describe them as landrace dogs, because they adapt to natural and post-zygotic selection are locally adapted to both the environment and the task. The task of guarding livestock requires attention, trust and protection, and these behaviors are not trainable (with operant conditioning), but these are results of early socialization in the first year of life of the pups.

Livestock guardian and herding dogs vary in size, color and shape. Herding dogs have the work of conducting livestock from one place to another one causing fearflocking behavior. Herding dogs share an instinctive ability to control the movement of other animals. Herding breeds were developed to gather, herd and protect livestock (AKC, 2018). These dogs are divided into headers, heelers and catch dogs depending on their specific tendency. Unlikely livestock guarding dogs, herding dogs depend on a behavioral conformation of specific integrated sequences of movement (Lord, Schneider, \& Coppinger, 2017). Amongst the herding dogs breeds are: 
Australian cattle, Beauceron, Belgian Malinois, Border Collie, Briard, amongst others.

\section{The pet care market}

The pet care market is segmented into veterinary care, pet food, insurance, supplies, medication, live animal purchase, dog walking, grooming and boarding services.

Tesfom \& Birch (2010) in a survey based study in the United States, found that dog owners are more loyal to dog food brands than human food brands. Also, the study reveals that dog owners are more sensitive to human food price than dog food price. Furthermore, results of this research also show that dog owners are more serious about buying healthy dog food than buying healthy human food.

Euromonitor launched in March 2018 the trend report on pet care for this year. In this report it is estimated that the world market for pet care currently reaches 109 billion dollars. In an investigation by the insurance company Sainsbury included in the report, it was found that 46 percent of dog or cat owners say they take more photos of their pets than their partners, and 26 percent report taking more photos to pets than to his human children.

\section{Pet food market}

The market size of the pet food market in 2017 reached USD 27 billion in the United States, and it has continuously growing (Packaged Facts, 2017); and it is projected to reach worldwide USD 98.81 by 2022 (Grand View Research, 2018). Beaton (2018) analyses that the increasing growth in the global pet food market driven by two specific factors humanization of pets, and premiumization. However, David Sprinkle, research director for Packaged Facts (2017), explains that the growth in this market can be explained by rapid acceleration of online sales, plus the emergence of Millennials as noteworthy pet market consumers.

\section{Pet insurance}

Remarkably, pet insurance has been around as long as human health insurance, being first established in Sweden in 1890 (McConnell \& Drent, 2010). However, it was not until the famous dog, Lassie, first received a pet insurance policy in 1982 that pet insurance became an official choice. According to the North American Pet Health Insurance Association (2018), there are 179 million pets in North America, with close to 2.07 million pets being insured at year-end 2017, representing an increase of $16.8 \%$ from 2016 (North American Pet Health Insurance Association, 2018). According to the same source, approximately 1.83 million pets were insured in the United States and 244,000 in Canada. In the U.S., $98 \%$ of those insured pets were covered either through an Insurance with Embedded Wellness plan or an Accident \& IIIness plan, whereas the remaining $2 \%$ were covered through a simple Accident Only plan.

Notably, the annual average growth rate in the US market of pet insurance since 2013 is $19.8 \%$, whereas the responding in the Canadian market is $15.3 \%$, thus 
indicating the increased awareness and engagement of pet owners (North American Pet Health Insurance Association, 2018).

\title{
Pet-friendly work environments
}

Gurchiek (2018) analyses how pet-friendly policies could translate into employee engagement and retention. In a study to 2002 full-time employees in a pet-friendly the company U.S. HABRI and Nationwide in Ohio in the United States, it was found that $90 \%$ of the workers feel highly connected to their company mission.

In a similar vein, Barker et al. (2012) conducted an experiment where for a period of one week, they divided 76 of a company's employees into the following three categories: eighteen employees who owned dogs and took their dog to work, thirtyeight employees dog owners who did not take their dog to work and nineteen employees who did not pet. Barker et al. asked the employees to report how stressed they were four times a day. Remarkably, employees with dogs with them had always reported the lowest stress levels. The scholars emphasized, of course that, the benefits are much more than a reduced stress level. Employees - dog owners who had their pets with them, felt more support from the company's management team. Furthermore, participants' comments illustrated a number of potential benefits for animal-friendly companies, including a) increased productivity; b) increased morale; c) increased co-operation.

\section{Pawternity leave}

For companies to be transformed into pet-friendly environment or considering pawternity leave, Gurchiek (2018) proposes the further considerations for employers:

1. Diversity with the pet definition. Pets aren't only dogs and cats. Fish, lizards, parrots, etc. are company animals and family members. Providing a stratification of pets, and giving more value to dogs and cats, might have negative effects. 2. Time allowance. How much would the company give?, which criteria? Per pet?, age? Health condition?

3. Employees with no pets. Which similar benefits could be provided to employees with no pets?

\section{Pet friendly work environments: Cases}

\author{
Amazon \\ In recent years, a growing number of companies, although that number is still fairly \\ small, have realized the benefits of becoming dog-friendly, thus allowing their \\ employees to come to work with their pet (Colarelli, McDonald, Christensen, \& \\ Honts, 2017). In this light, they are also setting up special places for the pets to play \\ and enjoy their time, while their human friends are working.
}

One of these companies is Amazon, which had proudly published on their blog pictures from their headquarters in Seattle featuring some of the 6,000 pets that 
accompany their human friends in the company. And all thanks to Rufus, a Welsh Corgi who had visited Amazon 10 years ago along with his human friend, an Amazon executive. Rufus had regularly participated in all meetings, meetings, breaks and had soon won the employees' hearts. The positive impact of Rufus' interaction with the employees, had led Amazon's executive team to allow their employees to come to work with their pets. Many of these puppies have their own profile on the Dogs of Amazon section of the Amazon webpage, whereas the Amazon's "Woof Pack" Manager, ensures that both the dogs are happy, and that Amazonians are enjoying this the most (Umoh, 2018).

\section{Google}

At Alphabet, née Google, pets are enshrined in the Google code of conduct (Hook, 2017). Specifically, they state that "Google's affection for our canine friends is an integral facet of our corporate culture. We like cats, but we're a dog company, so as a general rule we feel cats visiting our offices would be fairly stressed out" (Alphabet, 2018). Amenities include the provision of a doggie bus, both for dogs and their human friends who have to commute to the office from San Francisco.

\section{Denver Airport}

The largest airport therapy animal program in the United States is been hosted at the Denver International Airport (Denver Airport, n.d.). The Canine Airport Therapy Squad (CATS) are a squad of at least 100 dogs, and one cat, thus representing at least 40 breeds. The Squad consists of four-legged keen volunteers whose duties include giving pleasure to travelers with a furry cuddle or a friendly wag. Denver International Airport's visitors can encounter these special employees throughout the airport, wearing their unique blue plaid "Pet Me" vests.

\section{Arkix S.A.}

Arkix is a Colombian digital marketing agency founded in 2005 with nearly 180 employees. Arkix main office is located in las Palmas neighborhood in Medellin. Mr. Misael Martinez is the general manager. Arkix is expert in digital consulting, construction and operation of digital marketing strategies, relational marketing and advertising, as well as app and web development.

Arkix is pet friendly since 2014. Mr. Federico Alvarez Zuluaga, SEO leader, told us that company was moved from an office in a building to a big house. A stray dog arrived to the house days after the company moved and an employee filed a petition to the managers to make Arkix Pet Friendly.

"Anti-dogs colleagues or clients have not said anything yet. Most people in the company are pro-dogs, we can have up to 15 dogs on one day in Arkix" told us Federico.

Federico often goes with his female dog "Jani" to work. Jani means for Federico support and company, most of the time she's with him. "One of the best things of Arkix is that I can bring my dog" Federico states. "Jani isn't not my daughter, Jani is my pet. We cannot humanize our pets, we have them to keep us company but we can't treat them or love them as other human. I try to take Jani everywhere I can, like dog parks, hiking, to my country-house, to the office, shopping malls (I never go on busy hours) but I never take Jani to other people's homes", Federico clarifies. 
Most pet friendly work experiences are related to dogs and not other domestic animals. "About two months ago Arkix adopted two stray cats, but were very difficult to handle. They were adopted and took home by two employees afterwards", describes Federico.

"Dogs are not exotic animals and are not dangerous in most cases. Dogs are easy to learn, they follow instructions and commands, they are easy to handle and they don't cause allergies as much as cats", Federico further explains.

\section{Pawternity leave}

In Arkix, pawternity leaves are valid if its strictly necessary. When a pawternity leave is granted, then people are allowed/expected to work from home.

"Some companies might oppose to be pet friendly because they might think that employees won't be as productive as they need to be because they also need to take care of the dog. Also, they don't want to handle the mess that dogs can do" Federico explains.

\section{Pet friendly work environment: gains and regulations}

Federico describes the gains of working in a pet friendly company, "It's really fun to work and people actually enjoy the presence of dogs. Those who have dogs love to work at a pet friendly company because they don't need to leave their dogs alone at their house."

"We have a pet regulation that outlines the rules that dogs must follow in the office. Arkix also has a pet committee, this allows us to control what dogs do at the office. We need to pick up after our dogs, they go on the big backyard that surrounds the house. If we see other dog poop we also need to pick it up because we are a team. On Thursdays dogs are not allowed to come into Arkix because that day they do a deep cleaning of the house, dogs can't come when it's raining really hard because they can make a mess. Dogs also have a space for their food and water not inside the office" Mr. Federico Alvarez Zuluaga, SEO leader of Arkix.

\section{Conclusions:}

With this paper we have included dogs in the management of diversity academic literature. In this study, a review of the relationship between humans and people was presented, as well as a review of attitudes and perception towards animals. It also presented an in-depth analysis of the evolution of the intimate bond and the profound relationship between dogs and humans. Additionally, some of the multiple work functions that dogs exercise as substitutes to working people at the service of humans (in productive, entertainment and therapeutic activities) were described . It was Some financial dimensions and economic considerations of the pet care market were also reviewed in this paper. 
Finally, we presented some cases of pet friendly work environments.

As authors, we are left with many questions for future studies. Are dogs part of a firm's human resources? Are dogs considered as an annex to a particular individual? Are the responsibility of companies and human resources departments the welfare programs of dogs in organizations?

Studies related to the business case of dogs in organizations, can contribute to give figures on the financial benefit of achieving successful transition to be pet friendly organizations.

It is also important to increase the number of empirical cases documenting both successes and failures of pet friendly organizations. There are definitely challenges and discussions to be had about the inter-species coexistence, but also about the mechanisms that must be put in place to ensure the welfare of both dogs and humans. Will it be times for human resources departments moving beyond anthropocentric needs?

We also note in the cases we reviewed, that dogs occupy a higher place in the hierarchy of pets. This should also be reviewed, since there is not much published evidence of pet friendly work environments open to other pets. Does George Orwell's famous phrase in Animal Farm apply "All animals are equal, but some animals are more equal than others" in this case?

Interdisciplinary work between management, ethology, psychology, veterinary sciences, anthropology, biology, and sociology can be fundamental to increase our understanding of the implications of not advancing towards being open societies to diversity. We definitely identify the need, from ethology-based studies on animal behavior in human work environments.

This particular study proposes that diversity should include dimensions such as families with dogs, and organizations open to dogs. Being open to going beyond anthropocentric positions can help us understand differences, and understand others.

We believe that bringing this issue to the academic agenda and management practice invites both managers and academics to reflect on the organizations in the basic needs of others. By having organizations that are pet friendly, we should consider sleep, exercise, love, drink, food, toilet, and discipline on the agenda. It involves challenges such as ensuring decent conditions for dogs. It is for those responsible for health \& safety to design and implement practices and procedures for making office safe for dogs. 


\section{Acknowledgements:}

Authors would like to recognize the great support received by their encouraging and very talented research assistants and most loving and loyal companions both in Cyprus and Colombia: Maya (pitbull), Cian Felipe (miniature pinscher), Tiwaz Andres (Italian greyhound), and Valentin Amado (Italian greyhound). We would like to imagine, they are proud and happy we finally wrote this paper (with the support of Miguel Olivas-Lujan) to contribute a more inclusive and open world to diversity.

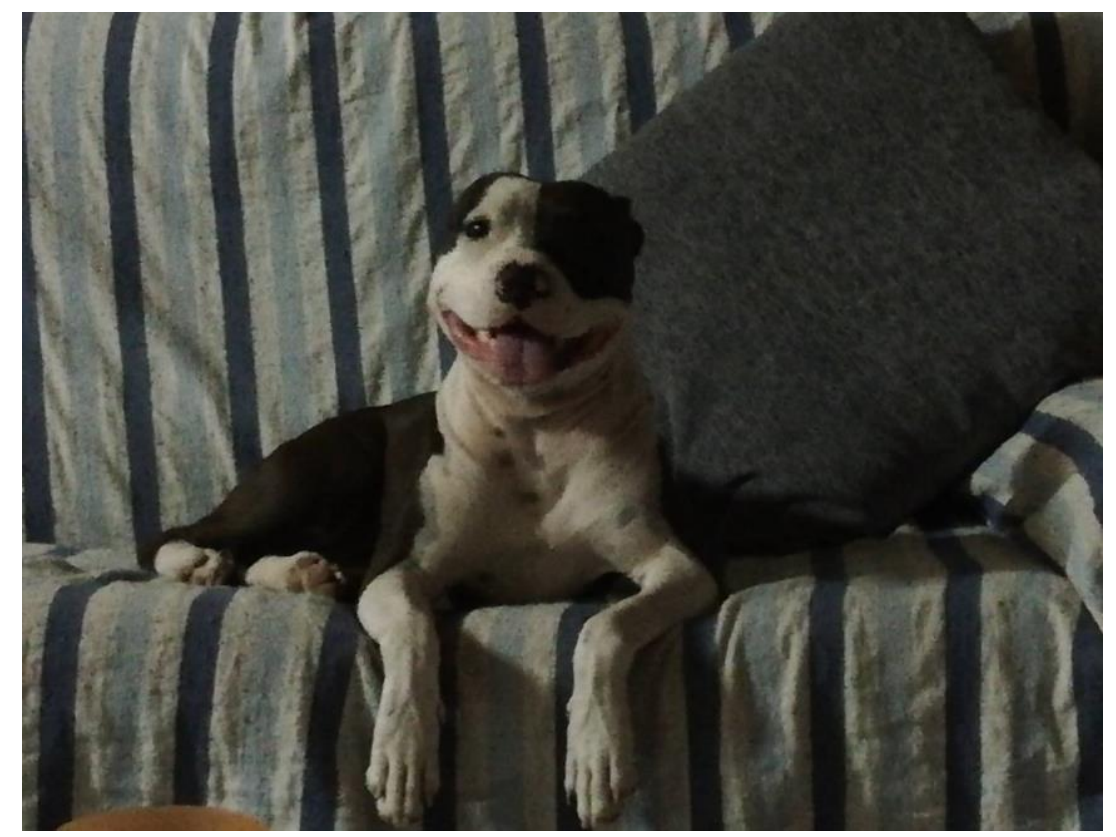

Picture 1: Maya - Cyprus

Picture 2: Cian Felipe- Colombia

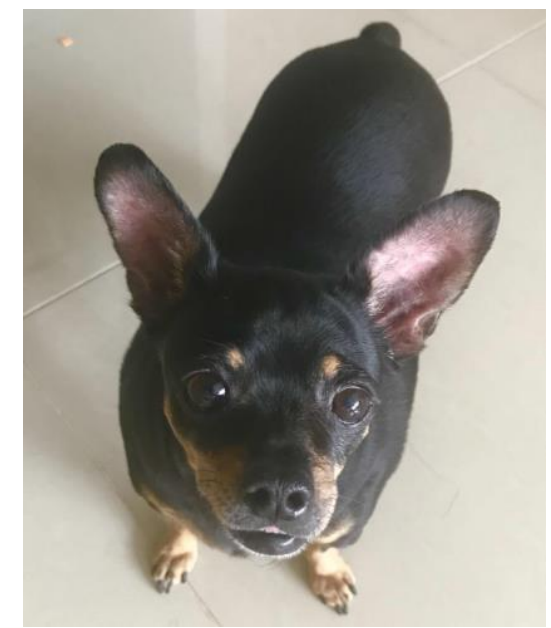

Picture 3: Tiwaz Andres \& Valentin AmadoColombia

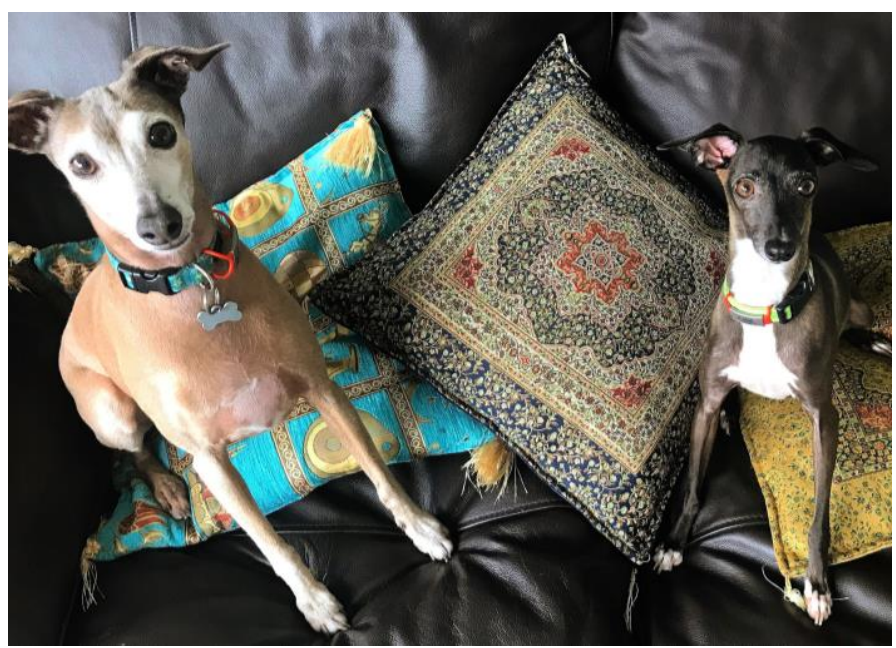




\section{References:}

AKC (2018) Herding Group. American Kennel Association. Available online at: https://www.akc.org/dog-breeds/groups/herding/.

American Pet Products Association (APPA) (2018). Report: 2017-2018 APPA National Pet Owners Survey. Available online at: https://www.americanpetproducts.org/press industrytrends.asp.

Angle, C., Waggoner, L., Ferrando, A., Haney, P., \& Passler, T. (2016). Canine Detection of the Volatilome: A Review of Implications for Pathogen and Disease Detection. Frontiers in Veterinary Science, 3(47), 1-7. doi:10.3389/fvets.2016.00047.

Barker, R. T., Knisely, J. S., Barker, S. B., Cobb, R. K., \& Schubert, C. M. (2012). Preliminary investigation of employee's dog presence on stress and organizational perceptions. International Journal of Workplace Health Management, 5(1), 15-30.

Batt, S. (2009). Human attitudes towards animals in relation to species similarity to humans: a multivariate approach. Bioscience horizons, 2(2), 180-190.

Beaton, L. (2018) What's driving global pet market growth? Pet Food Industry. Available online at: http://www.petfoodindustrydigital.com/201803/index.php\#/46.

Beetz, A.; Uvnäs-Moberg, K.; Julius, H. \& Kotrschal, K. (2012). Psychosocial and Psychophysiological Effects of Human-Animal Interactions: The Possible Role of Oxytocin. Frontiers in Psychology, 4(3), 1-15 https://doi.org/10.3389/fpsyg.2012.00234

Berget, B., Ekeberg, Ø., \& Braastad, B. O. (2008). Animal-assisted therapy with farm animals for persons with psychiatric disorders: effects on self-efficacy, coping ability and quality of life, a randomized controlled trial. Clinical practice and epidemiology in mental health , 4(9), 1-7.

Bjerke, T., \& Østdahl, T. (2004). Animal-related attitudes and activities in an urban population. Anthrozoös, 17(2), 109-129.

Bowlby, J. (1958). The nature of the child's tie to his mother. International Journal of Psycho-Analysis, 39, 350-373.

Carter, S.(2016). Is there a place for dogs in public space, or must they make do with 'dog parks'?. The Conversation. Available online at:

https://theconversation.com/is-there-a-place-for-dogs-in-public-space-or-mustthey-make-do-with-dog-parks-56147

Charles, N. (2016). Post-Human Families? Dog-Human Relations in the Domestic Sphere. Sociological research online. 21(3), 1-12. https://doi.org/10.5153/sro.3975 
Church, J., \& Williams, H. (2001). Another sniffer dog for the clinic? The Lancet, 358(9285), P930.

Clutton-Brock, J.; Corbet, G.B. \& Hills, Mi. (1976). A review of the family Canidae, with a classification by numerical methods. Bulletin of the British Museum (Natural History), 29, 177-199. https://doi.org/10.5962/bhl.part.6922

Cohen, M. R. (1973). Environmental information versus environmental attitudes. The Journal of Environmental Education, 5(2), 5-8.

Colarelli, S. M., McDonald, A. M., Christensen, M. S., \& Honts, C. (2017). A Companion Dog Increases Prosocial Behavior in Work Groups. Anthrozoös: A multidisciplinary journal of the interactions of people and animals, 30(1), 7789.

Cunningham, P. F. (1995). Topics awaiting study: Investigable questions on animal issues. Society \& Animals, 3(1), 89-106.

Darwin, C. (1868). The variation of animals and plans under domestication. London: John Murray, Albemarle Street. Available online at: http://darwinonline.org.uk/content/frameset?pageseq=1\&itemID=F878.1\&viewtype=text

Deffler, S.A.; Fox, C.; Ogle, C.M. \& Rubin, D.C. (2016). All my children: The roles of semantic category and phonetic similarity in the misnaming of familiar individuals. Memory \& Cognition, 44 (7), 989-99. https://doi.org/10.3758/s13421-016-0613-z

Denver Airport. (n.d.). Denver International Airport. Retrieved July 22, 2018, from https://www.flydenver.com/cats

Fine, A. (2010). Handbook on animal assisted therapy.(3 ${ }^{\text {rd }}$ ed.). London: Elsevier Inc.

Foer, J. S. (2006, November 27). My life as a dog. New York Times, p. A25.

Furton, K. G., \& Myers, L. J. (2001). The scientific foundation and efficacy of the use of canines as chemical detectors for explosives. Talanta, 54(3), 487-500.

Gillespie, K. \& Lawson, V. (2017). My Dog is My Home: multispecies care and poverty politics in Los Angeles, California and Austin, Texas. Gender, place and culture: A Journal of Feminist Geography, 24(6), 774-793. https://www.tandfonline.com/doi/full/10.1080/0966369X.2017.1339021

Grand View Research Inc (2018). Pet Food Market Size Worth $\$ 98.81$ Billion By 2022 - CAGR 4.3\%. Available online at:

https://www.grandviewresearch.com/press-release/global-pet-food-market

Gurchiek, K. (2018). Pawternity Leave Acknowledges Pet Owners' Needs. Society for Human Resource Management (SHRM). Available online at: https://www.shrm.org/ResourcesAndTools/hrtopics/benefits/Pages/Pawternity-Leave-Acknowledges-Pet-OwnersNeeds.aspx 
Hall, S., Dolling, L., Bristow, K., Fuller, T. \& Mills, D.S. (2017). Companion Animal Economics: The Economic Impact of Companion Animals in the UK. CAB International: Oxfordshire, UK.

Hoffmann, A. O., Lee, A. H., Wertenauer, F., Ricken, R., Jansen, J. J., Gallinat, J., \& Lang, U. E. (2009). Dog-assisted intervention significantly reduces anxiety in hospitalized patients with major depression. European Journal of Integrative Medicine, 1(3), 145-148.

Hook, L. (2017, May 12). Why Silicon Valley has embraced the 'office dog'. Financial TImes. Retrieved from https://www.ft.com/content/dbb96e96-3506-11e7-bce4$\underline{9023 f 8 c 0 f d 2 e}$

Hsu, S.-J., \& Roth, R. E. (1996). An assessment of environmental knowledge and attitudes held by community leaders in the Hualien area of Taiwan. The Journal of Environmental Education, 28(1), 24-31.

Jackson, J. (2012). Animal-assisted therapy: the human-animal bond in relation to human health and wellness. Winona: Winona State University.

Kellert, S. R. (1993). Attitudes, knowledge, and behavior toward wildlife among the industrial superpowers: United States, Japan, and Germany. Journal of social issues, 49(1), 53-69.

Kellert, S. R. (1997). The value of life: Biological diversity and human society.(1 ${ }^{\text {st }}$ ed.). Washington, D.C., USA: Island Press/ Shearwater Books.

Klontz, B. T., Bivens, A., Leinart, D., \& Klontz, T. (2007). The effectiveness of equine-assisted experiential therapy: Results of an open clinical trial. Society \& Animals, 15(3), 257-267.

Kovács, K., Virányi, Z., Kis, A., Turcsán, B., Hudecz, Á., Marmota, M.T, Koller, D., Rónai, Z., Gácsi, M. \& Topál, J. (2018). Dog-Owner Attachment Is Associated With Oxytocin Receptor Gene Polymorphisms in Both Parties. A Comparative Study on Austrian and Hungarian Border Collies. Frontiers in Psychology, 9, 1-15. https://doi.org/10.3389/fpsyg.2018.00435

Kovács, Z., Kis, R., Rózsa, S., \& Rózsa, L. (2004). Animal-assisted therapy for middle-aged schizophrenic patients living in a social institution. A pilot study. Clinical Rehabilitation , 18(5), 483-486.

Lang, U. E., Jansen, J. B., Wertenauer, F., Gallinat, J., \& Rapp, M. A. (2010). Reduced anxiety during dog assisted interviews in acute schizophrenic patients. European Journal of Integrative Medicine, 2(3), 123-127.

Leitch, O., Anderson, A., Kirkbride, K., \& Lennard, C. (2013). Biological organisms as volatile compound detectors: A review. Forensic Science International, 232(13), 92-103.

Levinson, B. M. (1969). Pet-oriented child psychotherapy.( $1^{\text {st }}$ ed.). Springfield, Illinois, USA: Charles C. Thomas. 
Lindemann- Matthies, P. (2005). 'Loveable'mammals and 'lifeless' plants: how children's interest in common local organisms can be enhanced through observation of nature. International journal of science education , 27(6), 655677.

Lord, K; Schneider, R.A. \& Coppinger, R. (2017). Evolution of working dogs. In Serpell, J. (Ed) The Domestic Dog: Its evolution, behavior and interactions with people. $2^{\text {nd }}$ Ed. Cambridge University Press: Cambridge.

Lorenzo, N., Wan, T., Harper, R. J., Hsu, Y.-L., Chow, M., Rose, S., \& Furton, K. G. (2003). Laboratory and field experiments used to identify Canis lupus var. familiaris active odor signature chemicals from drugs, explosives, and humans. Anal Bioanal Chem, 376, 1212-1224. doi:10.1007/s00216-003-20187

Mader, B., Hart, L., \& Bergin, B. (1989). Social Acknowledgments for Children with Disabilities: Effects of Service Dogs. Child Development, 60(6), 1529-1534

McConnell, C., \& Drent, D. P. (2010). Enabling Best Care: How Pet Insurance Can Help. 2010 Western Veterinary Conference. Veterinary Pet Insurance Company.

Medical Detection Dogs. (2018, August 17). Retrieved from https://www.medicaldetectiondogs.org.uk/our-history/

Morgan, W. P., \& Goldston, S. E. (2013). Exercise and mental health. New York: Taylor and Francis .

My Dog is My Home (2018). http://www.mydogismyhome.org

Nepps, P., Stewart, C., \& Bruckno, S. (2011). Animal-assisted therapy: Effects on stress, mood, and pain. Journal of Lancaster General Hospital, 6(2), 56-59.

Nightingale, F. (1992). Notes on nursing: What it is, and what it is not. .Philadelphia, PA, USA: Lippincott Williams \& Wilkins.

North American Pet Health Insurance Association (2018, August 17). Retrieved from https://naphia.org/industry/

North American Pet Health Insurance Association (2018). State of the industry report 2018: Highlights. North American Pet Health Insurance Association.

Nurenberg, J., Schleifer, S., Madara, B., Yellin, M., Desai, P., Shaffer, T., \& Allen, A. (2011). Equine assisted psychotherapy for patients with severe chronic psychiatric disorders. Honolulu, Hawaii: Annual Meeting of the American Psychiatric Association.

Packaged Facts (2017) Pet Food in the U.S., $13^{\text {th }}$ Edition. Available online at: https://www.packagedfacts.com/pet-products-services-c124/ 
Pedersen, I., Martinsen, E. W., Berget, B., \& Braastad, B. O. (2012). Farm animalassisted intervention for people with clinical depression: a randomized controlled trial. Anthrozoös , 25(2), 149-160.

Pifer, L., Shimizu, K., \& Pifer, R. (1994). Public attitudes toward animal research: Some international comparisons. Society \& Animals 2, 2(2), 95-113.

Poresky, R. H. (1990). The young children's empathy measure: Reliability, validity and effects of companion animal bonding. Psychological Reports, 66(3), 931936.

Riede, D. (1987). The relationship between man and horse with reference to medicine throughout the ages. People-Animals-Environment, 5(2), 26-28.

Schenk, R., Pollatos, O., Schenk, S., \& Schandry, R. (2009). Animal-assisted therapy with dolphins in eating disorders. Retrieved 08 07, 2018, from https://epub.ub.unimuenchen.de/9507/1/Manuskript pollatis schandry schenk.18.02.Rainer.pdf

Serpell, James (2017). The Domestic Dog: Its evolution, behavior and interactions with people. $2^{\text {nd }}$ Ed. Cambridge University Press: Cambridge.

Sloane, C. F. (1955). Dogs in War, Police Work and on Patrol. Journal of Criminal Law and Criminology, 46(3), 385-395.

Statista (2018) Number of dogs in the United States from 2000 to 2017 (in millions). The Statistics Portal. Available online at: https://www.statista.com/statistics/198100/dogs-in-the-united-states-since$\underline{2000 /}$

Tesfom, G. \& Birch, N. (2010). Do they buy for their dogs the way they buy for themselves?. Psychology \& Marketing, 27 (9), 898-912.

Thompson, M. J. (2009). Animal-Assisted Play Therapy: Canines As Co-Therapists. In G. Walz, J. Bleuer, \& R. Yep (Eds.), Compelling counselling interventions: VISTAS 2009(pp. 199-209). Alexandria, VA: American Counseling Association.

Topál, J.; Miklósi,A.; Csányi, V. \& Doka, A. (1998). Attachment behavior in dogs (Canis familiaris): a new application of Ainsworth's (1969) Strange Situation Test. Journal of Comparative Psychology, 112(3), 219-229. http://dx.doi.org/10.1037/0735-7036.112.3.219

Triebenbacher, S. L. (1998). Pets as transitional objects: Their role in children's emotional development. Psychological reports, 82(1), 191-200.

Trivedi, L., \& Perl, J. (1995). Animal facilitated counseling in the elementary school: A literature review and practical considerations. Elementary School Guidance \& Counseling , 29(3), 223-234.

Umoh, R. (2018, April 14). There are 6,000 dogs 'working' at Amazon and they get access to these cool perks. CNBC. Retrieved from 
https://www.cnbc.com/2018/04/13/meet-some-of-the-6000-dogs-working-atamazon.html

Urichuk, L. J., \& Anderson, D. L. (2003). Improving mental health through animalassisted therapy.Edmonton, Alberta, Canada: The Chimo Project .

Walsh, F. (2009). Human- animal bonds I: The relational significance of companion animals. Family process, 48(4), 462-480.

Williams, H., \& Pembroke, A. (1989). Sniffer dogs in the melanoma clinic? The Lancet, 333(8640), 734.

World Atlas (2018). Dog Population. Available online at:

https://www.worldatlas.com/articles/how-many-dogs-are-there-in-theworld.html 